\title{
Retention Rate and Efficacy of Perampanel with a Slow Titration Schedule in Adults
}

\author{
Mazen Basheikh, R. Mark Sadler
}

\begin{abstract}
Rationale: The manufacturer of perampanel (PER) suggests an initial adult dose of 2-4 mg/day and an upward dose titration of $2 \mathrm{mg}$ at no more frequently than 1- or 2-week intervals when used with enzyme-enhancing antiepileptic drugs (AEDs) or nonenzyme-enhancing AEDs, respectively. The general practice in our clinic is an initial dose of PER $2 \mathrm{mg} / \mathrm{day}$ and titrated by $2 \mathrm{mg} / 4$ weeks to an initial target of $6 \mathrm{mg} /$ day. Methods: Retrospective chart audit of patients starting PER in an adult epilepsy clinic between September 2013 and November 2016 with at least one 6-month follow-up visit was reviewed. Data collection included patient demographics, seizure characteristics, past and concurrent therapy, monthly seizure frequency before PER and at 6-month visit, and characteristics of PER discontinuation. Efficacy of treatment was assessed with the Engel classification and 50\% responder rate. Results: $N=102$ patients; mean age $=40$ years and $54 \%$ females. Focal onset seizures $85 \%$, generalized $13 \%$, and unknown $2 \%$. Median prior AED exposure $=6$ (range 3-20); median concomitant AED use $=2$ (range 1-5). Follow-up range was 6-37 months. The median seizure frequency/month prePER treatment was 6 (range $0-30$ ) for focal onset seizures and 1 (range $0-6$ ) for generalized seizures. The retention rate amongst all patients at 6 months was 78.4\%. At 6-month follow-up, 36\% of all patients achieved Engel class I (seizure freedom) (30.7\% of patients with focal onset seizures and $63.6 \%$ with generalized epilepsy). The $50 \%$ responder rate was $52 \%$ and $82 \%$ for focal and generalized epilepsy, respectively. Conclusion: PER has a good retention rate when titrated slowly and thus encouraging seizure freedom results in an otherwise medically refractory epilepsy population.
\end{abstract}

RÉSUMÉ : Taux de fidélité et efficacité du pérampanel chez des adultes bénéficiant d'un protocole de titration prudent. Justification : Le fabricant du pérampanel suggère pour les adultes une dose initiale de 2 à $4 \mathrm{mg}$ par jour et une titration à la hausse de $2 \mathrm{mg}$ à des intervalles ne dépassant pas 1 à 2 semaines lorsque ce médicament est utilisé respectivement avec des antiépileptiques inducteurs d'enzyme (AEIE) ou des antiépileptiques noninducteurs d'enzyme. La pratique générale dans notre clinique est d'administrer une dose initiale de pérampanel de 2 mg par jour et de l'augmenter de 2 mg pendant 4 semaines jusqu'à atteindre une cible de $6 \mathrm{mg}$ par jour. Méthodes : Nous avons analysé de façon rétrospective les dossiers de patients adultes d'une clinique de prise en charge de l'épilepsie ayant débuté un traitement au pérampanel entre septembre 2013 et novembre 2016 et ayant effectué au moins un suivi au bout de 6 mois. Notre collecte de données s'est attardée aux caractéristiques démographiques des patients, aux caractéristiques de leurs crises convulsives, à leurs traitements antérieurs et concomitants, à leur fréquence mensuelle de crises convulsives avant un traitement au pérampanel et au moment d'un suivi au sixième mois et aux caractéristiques liées à l'abandon du pérampanel. À noter que l'efficacité de ce traitement a été évaluée au moyen de la classification de Engel et en fonction d'un taux de réponse de $50 \%$. Résultats : Au total, les dossiers de 102 patients ont été analysés. Leur âge moyen était de 40 ans ; $54 \%$ d'entre eux étaient des femmes. De toutes les crises convulsives répertoriées, on a pu déterminer que $85 \%$ étaient partielles ou focales, que $13 \%$ étaient généralisées alors que pour seulement $2 \%$ d'entre elles le début restait inconnu. La durée médiane d'utilisation antérieure d'AEIE a totalisé 6 (étendue 3-20) ; l'utilisation médiane concomitante d'AEIE a quant à elle représenté 2 (étendue 1-5). L'étendue des périodes de suivi a par ailleurs varié de 6 à 37 mois. La fréquence médiane mensuelle de crises convulsives avant le début d'un traitement au pérampanel a été de 6 (étendue 0-30) pour les crises dites partielles ou focales et de 1 (étendue 0-6) pour les crises généralisées. Le taux de fidélité parmi tous les patients au bout de 6 mois était de 78,4\%. Au moment d'un suivi au sixième mois, $36 \%$ de tous les patients avaient atteint le niveau 1 de la classification de Engel, c'est-à-dire une absence de crises convulsives. Cette proportion était de 30,7 \% chez les patients ayant souffert de crises focales ou partielles et de $63,6 \%$ chez ceux ayant souffert de crises généralisées. En ce qui regarde un taux de réponse de $50 \%$, le pourcentage a été respectivement de $52 \%$ et $82 \%$ dans les cas de crises partielles ou focales et de crises généralisées. Conclusion : Le pérampanel possède ainsi un bon taux de fidélité lorsqu'on augmente sa dose lentement et donne à voir des résultats encourageants au sein d'une population atteint d'épilepsie médicalement réfractaire.

Keywords: Perampanel, Epilepsy

doi:10.1017/cjn.2020.174

Can J Neurol Sci. 2021; 48: 105-111

From the Department of Internal Medicine, Faculty of Medicine, University of Jeddah, Jeddah, Kingdom of Saudi Arabia (MB); and Department of Neurology, Dalhousie University, Halifax, Nova Scotia, Canada (RMS)

Received March 27, 2020. Final Revisions Submitted July 26, 2020. Date of Acceptance August 3, 2020.

Correspondence to: Mazen Basheikh, Department of Internal Medicine, University of Jeddah, Hamzah Ibn Al Qasim Street, Al Sharafeyah, Jeddah 23218, Kingdom of Saudi Arabia.

Email: mabasheik@uj.edu.sa 


\section{INTRODUCTION}

Perampanel [2-(2-oxo-1-phenyl-5-pyridin-2-yl-1,2-dihydropyridin3-yl) benzonitrile] (PER) is a novel antiepileptic drug (AED) with a reported mechanism of action that works as a noncompetitive and selective AMPA (amino-3-hydroxy-5-methyl4-isoxazolepropionic acid) receptor antagonist. It has been demonstrated to be useful in the treatment of both focal and generalized seizures. ${ }^{4-8}$ PER was approved for use in Canada in April 2013.

Several post marketing reports on the use of PER, mainly from Europe, are available. ${ }^{1,2}$

Dizziness, fatigue, headache, somnolence, and neuropsychiatric side effects, including irritability, anger, emotional liability, suicidal ideation, aggression, psychosis, and depression, all have been reported as potential side effects of this drug in these reports. These adverse side effects led to discontinuation of the medication in $15 \%-40 \%$ of the patients. ${ }^{1,2}$

Most of these reports had a titration rate of $2 \mathrm{mg} / 1-2$ weeks. PER has a long half-life (approximately 105 hours) indicating that the new steady-state serum level following each dose increment will be achieved in 17-21 days. ${ }^{9}$ A too rapid upward dose titration could result in a patient experiencing dose-related adverse effects, and withdrawing treatment, caused by a dose higher than required for seizure control.

A 2016 study suggested that a slower titration rate might be associated with lower side effects rates based on a limited number of patients. ${ }^{10}$

In Halifax at the QEII Health Science Centre, we prescribed PER for 124 patients between September 2013 and November 2016. All patients who were started on the drug had a titration rate of $2 \mathrm{mg} /$ day and increased by $2 \mathrm{mg}$ every 4 weeks.

Our hypothesis for this study was whether a slower titration of PER leads to a higher retention rate at 6 months.

\section{Method and Statistical Analysis}

All patients attending the adult epilepsy clinic of one epileptologist (RMS) who were prescribed PER with a starting dose of $2 \mathrm{mg}$ titrated by $2 \mathrm{mg}$ every 4 weeks between September 2013 and November 2016 and had at least one follow-up visit at 6 months were identified by review of the patients' charts.

Clinical data abstracted from the patients' charts included demographic data (gender and age when PER was started), seizure data (age of onset, seizure types, and frequency of each type before starting the medication and during scheduled followup visits) and medications data (previous and concomitant drugs). The highest dose the patient received and any reported adverse effects were documented. No presumed seizure etiology data was collected.

Exclusion criteria were titration of PER faster than $2 \mathrm{mg} / 4$ weeks; medication noncompliance or no follow-up visit.

Patients whose seizure frequency could not be assessed and/or had other therapeutic interventions less than 6 months after PER was started were included for the retention analysis but excluded from the efficacy analysis.

The retrospective chart review did not permit accurate assessment of the frequency of myoclonic jerks or focal aware seizures. These seizure types were excluded from efficacy analysis.

Efficacy of PER treatment was assessed in two ways: (a) the Engel classification and (b) $50 \%$ responder rate.

\section{Table 1: Engel classification}

\begin{tabular}{l|l}
\hline Engel class & Description \\
\hline Class I & $\begin{array}{l}\text { Seizure free or no more than a few early, nondisabling seizures; } \\
\text { or seizures upon drug withdrawal only }\end{array}$ \\
\hline Class II & $\begin{array}{l}\text { Disabling seizures occur rarely during a period of at least } \\
\text { 2 years; disabling seizures may have been more frequent soon } \\
\text { after surgery; nocturnal seizures }\end{array}$ \\
\hline Class III & $\begin{array}{l}\text { Worthwhile improvement; seizure reduction for prolonged } \\
\text { periods but less than 2 years }\end{array}$ \\
\hline Class IV & $\begin{array}{l}\text { No worthwhile improvement: some reduction, no reduction, or } \\
\text { worsening is possible }\end{array}$ \\
\hline
\end{tabular}

The Engel classification was originally proposed to describe the postoperative outcome of epilepsy surgery and has been extensively used for this purpose (Table 1). ${ }^{12}$ Although the Engel classification is not the standard measure of efficacy in most nonsurgical epilepsy research papers, this outcome classification provides, at a glance, information with respect to clinically meaningful improvement. The more traditional $50 \%$ responder rate provides data attesting to a measurable effect of the study drug on seizure frequency and is useful for regulatory drug trials. However, in the individual patient, a seizure frequency of, for example, 20/month that is reduced to 10 /month does not usually equate to any truly clinically meaningful benefit for the patient.

Descriptive statistics including mean ( \pm standard deviation), median (interquartile range), counts, and frequency were used, where appropriate, to summarize baseline clinical characteristics. Event rates and percentage change were reported based on documented cases with $95 \%$ confidence interval (CI). All analyses were performed using SAS STAT software version 9.4 (SAS, Cary, NC, USA).

This study was approved by Nova Scotia Health Authority Research Ethics Board.

\section{Results}

Between September 2013 and November 2016, 124 patients were prescribed PER; 102 patients met the entry criteria and were included for further analysis. Most of the excluded patients were due to either noncompliance, other medication changes or failure to attend follow-up visits after 6 months (Figure 1).

The mean age of the patients was $40.25(\mathrm{SD}=14.51)$ ranging between 18 and 72 years. The median number of past AED was 6 (range 3-20) $(\mathrm{SD}=2.84)$, and the median number of concomitant AEDs was 2 (range $=1-5, \mathrm{SD}=0.92$ ).

Tables 2 and 3 summarize the baseline demographics and clinical data of the patients.

\section{Retention Rate Analysis}

Retention rate at 6 months was $78.4 \%$ (80 patients) (Figure 2). Of those patients who were still taking the drug at 6 months, $50(62.5 \%)$ were still taking PER at their last clinic visit up to 37 months from starting the drug. For the other 30 patients, 18 discontinued after 6 months and 12 patients did not have a followup after the 6-month visit.

There were 22 patients $(21.57 \%)$ who developed adverse effects that led to discontinuation before 6 months. These patients 
Table 2: Patients baseline demographics

\begin{tabular}{l|c|c}
\hline & Number & Percent \\
\hline Male & 47 & 46.08 \\
\hline Female & 55 & 53.92 \\
\hline Focal onset epilepsy & 87 & 85.29 \\
\hline Generalized epilepsy & 13 & 12.75 \\
\hline Unknown epilepsy type & 2 & 1.96 \\
\hline
\end{tabular}

Table 3: Patients baseline clinical data

\begin{tabular}{l|c|c|c|c|c}
\hline & Mean & Std dev & Median & Min & Max \\
\hline Age when PER was started & 40.25 & 14.51 & 37 & 18 & 72 \\
\hline Age at seizure onset & 13.7 & 11.19 & 12 & 0 & 48 \\
\hline $\begin{array}{l}\text { Monthly frequency of focal } \\
\text { seizures at baseline }\end{array}$ & 9.25 & 9.69 & 6 & 0 & 30 \\
\hline $\begin{array}{l}\text { Monthly frequency of general } \\
\text { seizures at baseline }\end{array}$ & 1.48 & 1.66 & 1 & 0 & 5.5 \\
\hline $\begin{array}{l}\text { Time drug started to last } \\
\text { follow-up (months) }\end{array}$ & 7.2 & 4.2 & 6 & 6 & 37 \\
\hline Past AED at baseline & 6.1 & 2.84 & 6 & 3 & 20 \\
\hline Concomitant AED at baseline & 2.25 & 0.92 & 2 & 1 & 5 \\
\hline Concomitant at 6 months & 0.07 & 0.32 & 0 & 0 & 2 \\
\hline
\end{tabular}

Std dev=standard deviation.

Table 4: $50 \%$ responder rate at the 6-month visit for all the patients who were still taking the drug and not excluded from the efficacy analysis

\begin{tabular}{l|c|c|c|c}
\hline \multirow{2}{*}{ Epilepsy type } & \multirow{2}{*}{ Number (n) } & \multicolumn{2}{|c|}{$\begin{array}{c}\mathbf{5 0 \%} \text { reduction in seizure } \\
\text { frequency }\end{array}$} & $\begin{array}{c}\mathbf{5 0 \%} \\
\text { responder } \\
\text { rate }\end{array}$ \\
\cline { 3 - 4 } & & Yes & No & $51.92 \%$ \\
\hline Focal & 52 & 27 & 25 & $81.82 \%$ \\
\hline Generalized & 11 & 9 & 2 & \\
\hline
\end{tabular}

were included in the retention analysis but excluded from the efficacy analysis.

The adverse effects are detailed as follows: 15 patients (14.7\%) developed new onset or worsened neuropsychiatric symptoms including irritability, anger, emotional liability, and depression, 3 patients $(2.9 \%)$ developed dizziness, 3 patients (2.9\%) developed fatigue or somnolence, and 1 patient (1\%) with worsened seizures (Figure 3).

\section{Efficacy Analysis}

All patients who were included for the efficacy analysis at 6 months had a baseline frequency of at least 6 seizures per 6 months (minimum of one seizure per month) but the majority had more (mean seizure frequency per month $=9.25$; median $=6$ ).
The only exception is one patient who had a lower baseline seizure frequency ( 3 per year) and this patient did not achieve Engel class I because they had one seizure in the first 6 months of PER treatment.

The efficacy analyses for the Engel outcome are shown in Figures 4 and 5 and the 50\% responder rate in Table 4 .

The 16 patients and the reason(s) for exclusion from the efficacy analysis are depicted in Figure 6. Note that all these patients were included for the retention rate analysis.

\section{Efficacy in genetic generalized epilepsy at 6 Months}

Among the 11 patients with genetic generalized epilepsy (GGE), 7 (64\%) achieved an Engel class I outcome, 1 patient (9\%) with Engel class II, 2 patients (18\%) with Engel class III, and 1 patient (9\%) with Engel class IV (Figure 5).

\section{Efficacy in Focal Epilepsy at 6 Months}

Among 52 patients with focal epilepsy, the efficacy analysis revealed that 16 patients $(30.7 \%)$ achieved Engel class I, 3 patients (5.8\%) with Engel class II, 11 patients (21.2\%) with Engel class III, and 22 patients (42.3\%) with Engel class IV (Figure 6).

\section{Focal to Bilateral Tonic-Clonic Seizures at 6 Months}

Of the 68 patients with focal epilepsy, 18 patients experienced focal to bilateral Tonic-Clonic (TC) seizures prePER with a frequency of at least 1 per 6 months. At the 6-month visit, 12/18 (66.7\%) of these patients had their TC seizures abolished, 3 patients had significant reduction of focal to bilateral seizures, and 3 had no or minimal reduction of TC seizures.

\section{The Optimum Dose}

All patients started PER at a dose of $2 \mathrm{mg}$ and titrated to the maximum tolerable dose if seizure freedom was not achieved. Only 14 patients reached a maximum dose of $12 \mathrm{mg} /$ day. The optimum dose (defined as the optimum ratio of efficacy to adverse effects) was determined for some patients according to patients' and neurologist's overall impression but this was difficult to assess reliably in this retrospective review. Table 5 shows the recorded optimum dose where Table 6 shows the highest dose the patient received.

\section{The Increasing the Dose after 6 Months}

Although 28 patients had their PER dose gradually increased after the 6-month visit to $10-12 \mathrm{mg}$, only 3 patients had further benefit from increasing the dose without side effects. In total, 25/ 28 patients had their doses reduced back to 6-8 $\mathrm{mg}$ or PER was tapered gradually to discontinuation.

\section{Discussion}

This study reviews the experience of PER treatment in 102 patients with refractory epilepsy from a tertiary epilepsy care center with patient management supervised by one epileptologist.

This study provides a "real world" review of the efficacy and the safety of PER employing a slow titration schedule in a highly medically refractory epilepsy population. 


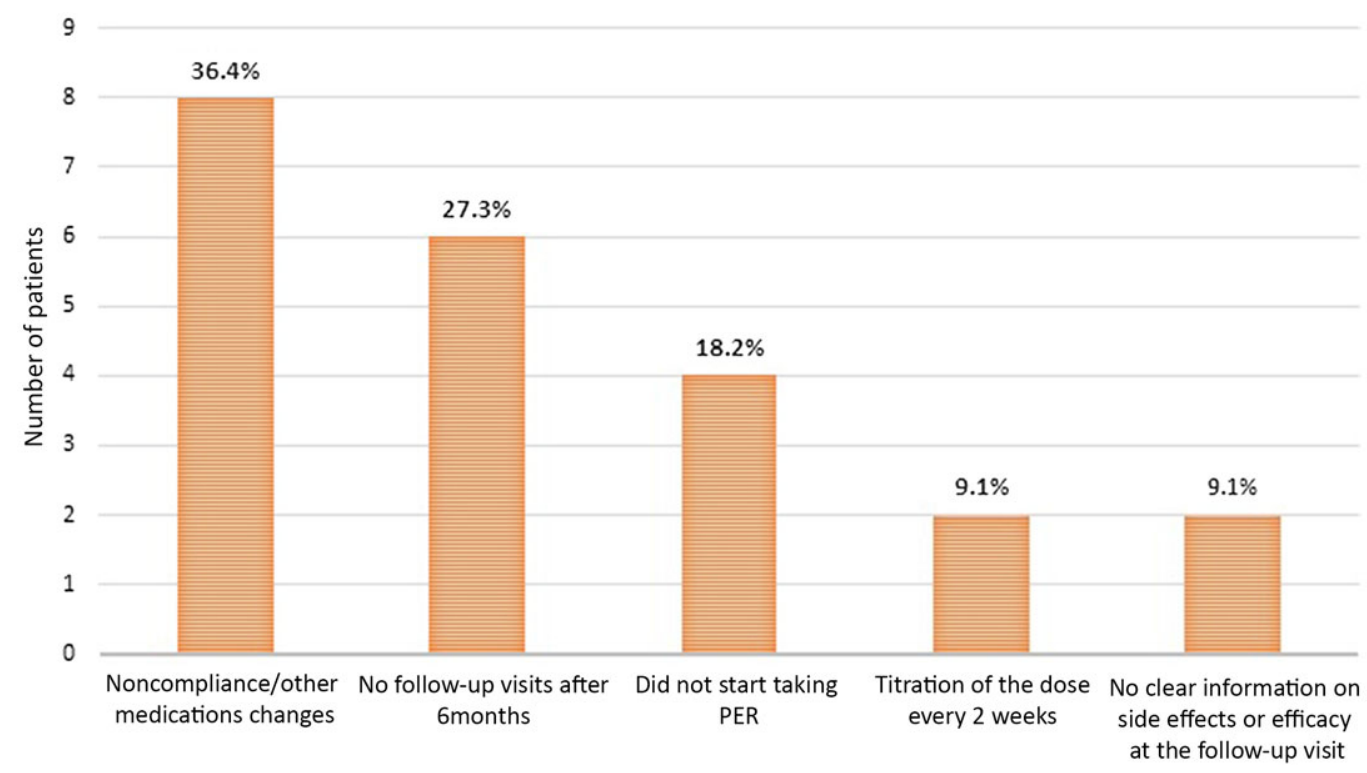

Figure 1: Reasons of exclusion of 22 patients.

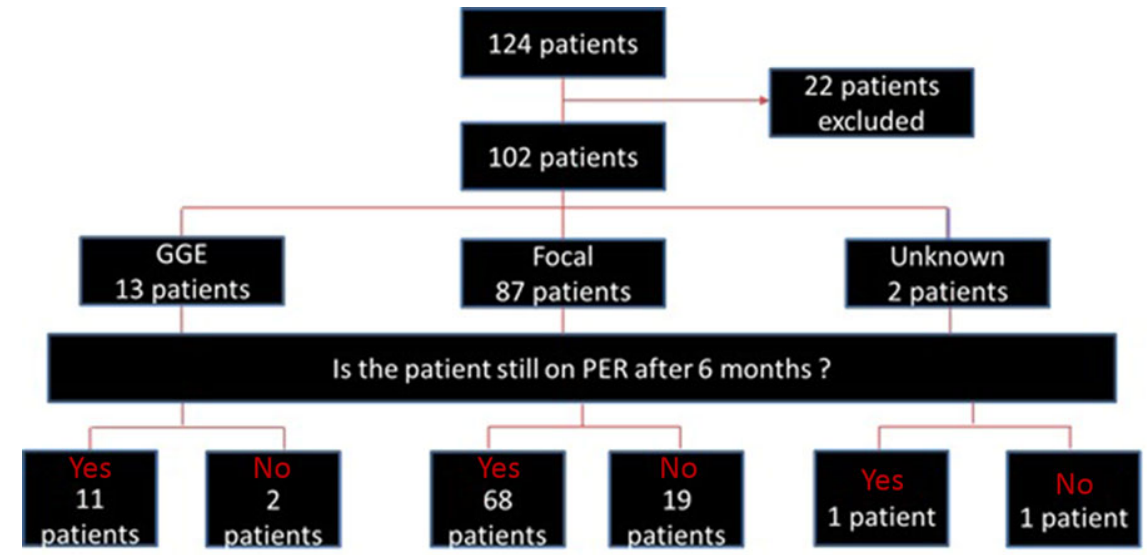

Figure 2: Retention rate at 6 months based on epilepsy type.

The 6-month retention rate was $78 \%$, achieved using a slow PER titration of $2 \mathrm{mg} / \mathrm{month}$ to an initial plateau of $6 \mathrm{mg} / \mathrm{day}$. While study methodologic differences do not allow a strict comparison to other reports, the retention rate in the current study compares favorably to reported retention rates of $60 \%-71 \%$ with more rapid titration. 1,2

In the present study, adverse effects leading to discontinuation occurred in 22 out of 102 patients $(21.57 \%)$ in less than 6 months. In comparison to other reported clinical experience from the UK and Ireland, the frequency of adverse effects leading to discontinuation was found to be $26.8 \%$ (83 out of 310 patients) with titration rate of $2 \mathrm{mg} / 2$ weeks. $^{2}$ Other reports from USA and South Korea showed discontinuation rates of $23 \%$ and $28.7 \%$, respectively. $^{3,11}$

Similar to most reports, the most frequent adverse effect leading to discontinuation of PER in this study was found to be neuropsychiatric side effects including irritability, anger, emotional lability, or depression. ${ }^{2,13}$
The efficacy of PER was perhaps higher than expected in an epilepsy population with a median past AED exposure of six. Many reports have demonstrated the extremely low probability of seizure control after a failure of three different regimens. ${ }^{14,15}$

In this study, patients with generalized epilepsy demonstrated a trend toward a better response (64\% Engel class I) than those with focal epilepsy (30.7\% Engel class I).

The efficacy analysis was not remarkably different compared to a Spanish study that showed significant reduction from the baseline seizure frequency by median change of $33 \%$. In that study, the effect was greater for secondarily generalized seizures (focal to bilateral TC), which had seizure reduction by $75 \%$. This study suggested that PER has better efficacy outcome in the secondary generalized seizure group. ${ }^{10}$ In our study, $83.3 \%$ of the patients with focal to bilateral TC seizures had significant reduction of those seizures.

The dose of $6 \mathrm{mg}$ daily was found to be the optimum dose for the majority of patients $(32.47 \%)$ followed by $8 \mathrm{mg}(14.3 \%)$. In 


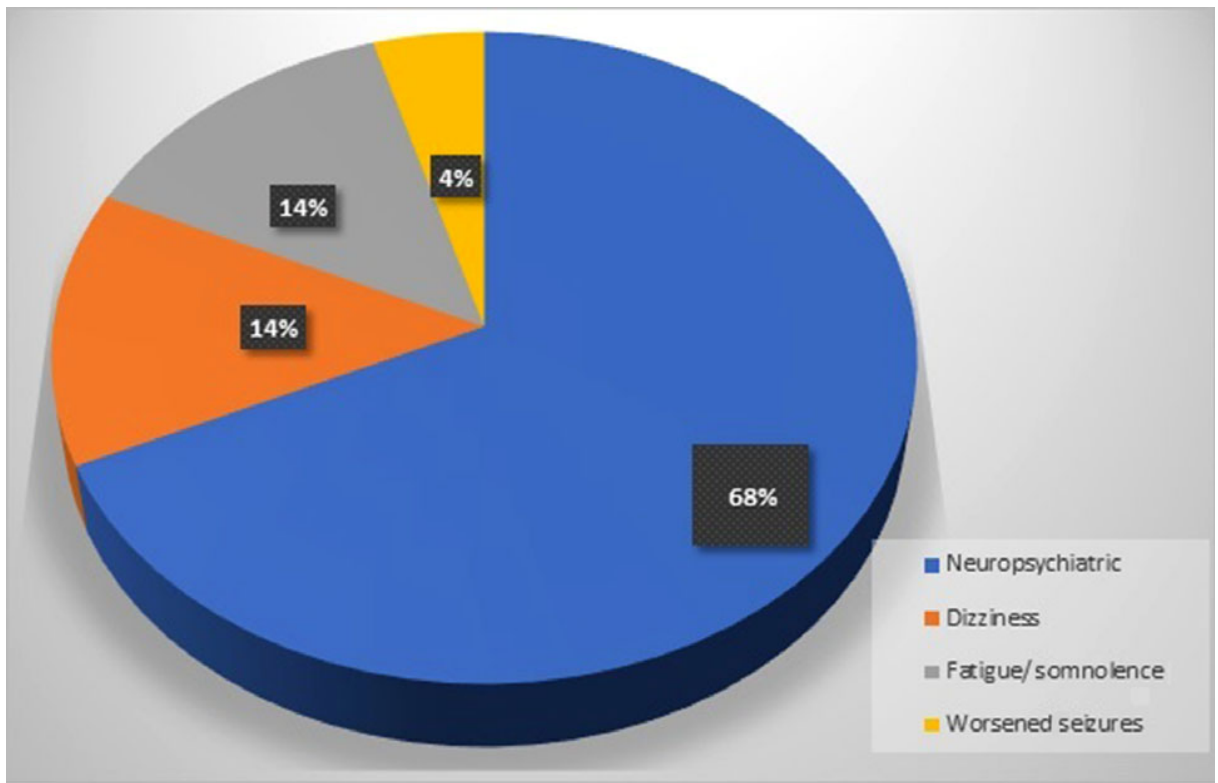

Figure 3: Analysis of the side effects that led to discontinuation.

25

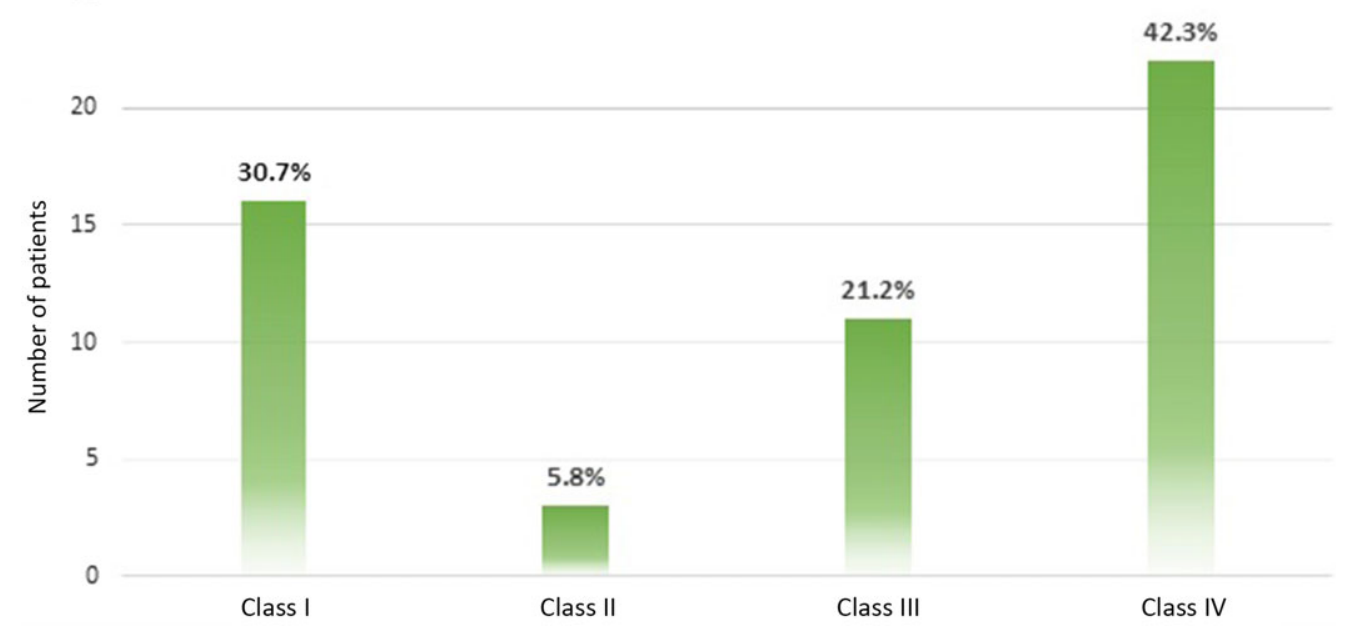

Figure 4: Efficacy in GGE at 6 months using Engel classification.

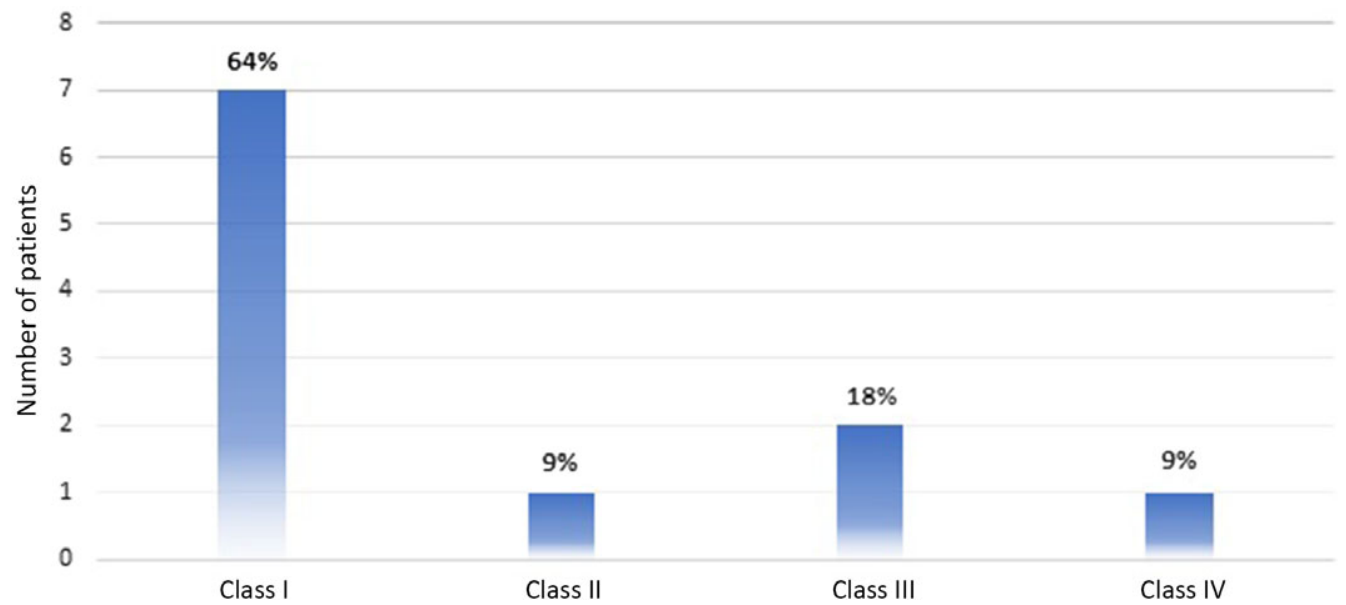

Figure 5: Efficacy in focal epilepsy at 6 months using Engel classification. 


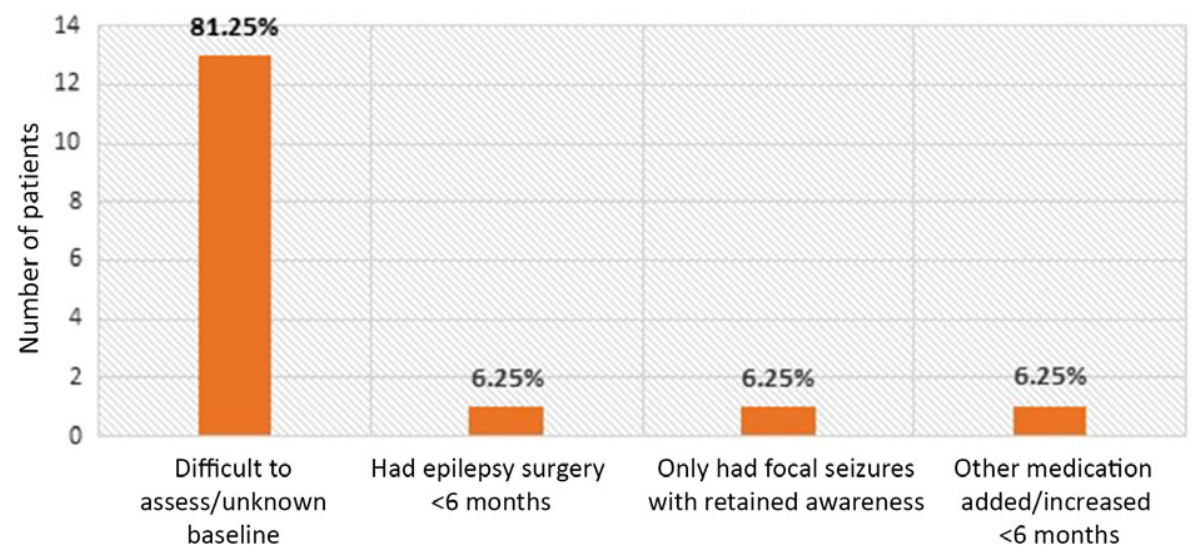

Figure 6: Patients excluded from efficacy analysis but included for retention rate analysis.

\section{Table 5: Reported optimum dose of perampanel}

\begin{tabular}{l|c|c}
\hline Dose mg/day & Frequency & Percent \\
\hline No optimum dose recorded & 25 & 28.57 \\
\hline 0 & 9 & 11.69 \\
\hline 2 & 2 & 2.60 \\
\hline 4 & 4 & 5.19 \\
\hline 6 & 25 & 32.47 \\
\hline 8 & 11 & 14.29 \\
\hline 10 & 1 & 1.30 \\
\hline 12 & 3 & 3.90 \\
\hline
\end{tabular}

Table 6: The highest dose the patient received

\begin{tabular}{l|c|c}
\hline Number & Frequency & Percent \\
\hline Missing & 2 & 2.60 \\
\hline 4 & 3 & 3.90 \\
\hline 6 & 24 & 31.17 \\
\hline 8 & 22 & 28.57 \\
\hline 10 & 12 & 15.58 \\
\hline 12 & 14 & 18.18 \\
\hline
\end{tabular}

total, 14 patients reached the maximum dose (12 $\mathrm{mg}$ once daily) but only 3 found that this was their optimum dose (Note: data was not collected on the potential interaction of PER dose with co-treatment with enzyme inducing or inhibiting AEDs). This observation suggests that doses higher than $8 \mathrm{mg}$ are associated with a higher risk of adverse effects without meaningful improvement in seizure control as only 3 of 28 patients $(10.7 \%)$ who had a dose increase up to $10-12 \mathrm{mg} /$ day had demonstrable benefit.

Some patients had an optimum response at low PER doses (two patients taking $2 \mathrm{mg} /$ day; four patients on $4 \mathrm{mg} /$ day). This low dose response is another potential advantage of a slower titration as patients may notice a beneficial effect of a low dose prior to reaching the planned initial dose plateau (e.g. $6 \mathrm{mg} /$ day).

This is the first observational adult study of PER in a clinical setting in Canada. One retrospective Canadian study of PER tolerability and adverse events in a pediatric and adolescent population has been published. ${ }^{13}$

Limitations of this study include that it is a retrospective study that lacks a comparative group using a faster titration that would allow comparison for the retention rate and efficacy. No attempt was made to determine response rates as a function of epilepsy etiology because the number of patients in each etiologic category would likely have been too small to allow any reliable conclusion.

Another limitation is not collecting data regarding the intellectual state of the patients (more specifically intellectual disability).

\section{Conclusion}

Prescribing PER to patients with refractory epilepsy, whether generalized or focal, using a slow titration schedule appears to be more tolerable and leads to a higher retention rate compared to faster titration.

A prospective randomized study with parallel "fast" and "slow" titration schedules would give a definite answer to this hypothesis.

\section{ACKNOWLEDGEMENTS}

We would like to acknowledge Ms. Susan Rahey for her help in data collection and editorial assistance in preparation of this paper.

\section{CONFLict OF INTEREST}

Dr. Sadler has received speakers' honoraria from Eisai Canada. Dr. Basheikh has no conflicts of interest to declare.

\section{Statement of Authorship}

MB: Conceptualization, methodology, investigation, writing original draft. RMS: Conceptualization, methodology, resources, writing - review \& editing, supervision. 


\section{REFERENCES}

1. Steinhoff BJ, Hamer H, Trinka E, et al. A multicenter survey of clinical experiences with perampanel in real life in Germany and Austria. Epilepsy Res. 2014;108:986-88.

2. Shah E, Reuber M, Goulding P, et al. Clinical experience with adjunctive perampanel in adult patients with uncontrolled epilepsy: a UK and Ireland multicentre study. Seizure. 2016;34:1-5.

3. Dong WK, Jeeyoung O. One-year retention study of adjunctive perampanel treatment in epilepsy patients. Clin Neuropharmacol. 2018;41:10-13.

4. French JA, Krauss GL, Biton V, et al. Adjunctive perampanel for refractory partial-onset seizures: randomized phase III study 304. Neurology. 2012;79(6):589-96.

5. French JA, Krauss GL, Steinhoff BJ, et al. Evaluation of adjunctive perampanel in patients with refractory-onset seizures: results of randomized global phase III study 305. Epilepsia. 2013;54(1): $117-25$.

6. Krauss GL, Serratosa JM, Villaneuva V, et al. Randomized phase III study 306: adjunctive perampanel for refractory partial-onset seizures. Neurology. 2012;78(18):1408-15.

7. Krauss GL, Perucca E, Ben-Menachem E, et al. Perampanel, a selective, noncompetitive <-amino-3-hydroxyl-5-methyl-4-isoxazolepropionic acid receptor antagonist, as adjunctive therapy for refractory partial-onset seizures: interim results from phase III, extension study 307. Epilepsia. 2013;54(1):117-25.
8. French JA, Krauss MD, Bibbiani MD, et al. Perampanel for tonicclonic seizures in idiopathic generalized epilepsy. Neurology. 2015;85(11):950-57.

9. Greenwood J, Valdes J. Perampanel (Fycompa): a review of clinical efficacy and safety in epilepsy. P T. 2016;41:683-98.

10. Villanueva V, Garcés M, López-González FJ, etal. Safety, efficacy and outcome-related factors of perampanel over 12 months in a real-world setting: the FYDATA study. Epilepsy Res. 126 (2016) 201-10.

11. Singh K, Shah YD, Luciano D, et al. Safety and efficacy of perampanel in children and adults with various epilepsy syndromes: a single-center postmarketing study. Epilepsy Behav. 2016;61:41-5.

12. Engel, J. Surgical treatment of the epilepsies. Philadelphia, PA: Lippincott Williams \& Wilkins; 1993. ISBN 0-88167-988-7.

13. Datta AN, Xu Q, Sachedina S, Boelman C, Huh L, Connolly MB. Clinical experience with perampanel for refractory pediatric epilepsy in one Canadian center. J Child Neurol. 2017;32:834-39.

14. Kwan P, Brodie MJ. Early identification of refractory epilepsy. N Engl J Med. 2000;342(5): 314-19.

15. Chen Z, Brodie MJ, Liew D, Kwan P. Treatment outcomes in patients with newly diagnosed epilepsy treated with established and new antiepileptic drugs a 30-year longitudinal cohort study. JAMA Neurol. 2018;75:279-286. doi: 10.1001/jamaneurol. 2017.3949. 